\title{
IAMJ
}

INTERNATIONAL

AYURVEDIC

MEDICAL JOURNAL

Review Article

ISSN: 2320-5091

Impact Factor: 6.719

\section{MANAGEMENT OF HYPERTENSION - AN AYURVEDIC REVIEW}

Garima Yadav $^{{ }^{*}}$, Pramod Kumar Mishra $^{2}$, Indu Sharma ${ }^{3}$,Lekha Soni ${ }^{4}$

${ }^{1}$ M.D. Scholar P.G Department of Kaya Chikitsa,

${ }^{2}$ Professor and Head of the Department, P.G Department of Kaya Chikitsa,

University College of Ayurveda, Dr Sarvapalli Radhakrishnan Rajasthan Ayurveda University Jodhpur, Rajasthan, India.

${ }^{3}$ Associate Professor P.G Department of Kaya Chikitsa, Govt. Ayurveda College of Udaipur, Rajasthan,

${ }^{4}$ M.D. Scholar P.G Department of Kaya Chikitsa,

Corresponding Author: ygarima527@gmail.com

\section{https://doi.org/10.46607/iamj2709102021}

(Published Online: October 2021)

Open Access

(C) International Ayurvedic Medical Journal, India 2021

Article Received: 25/09//2021 - Peer Reviewed: 06/10/2021 - Accepted for Publication: 07/10/2021

\section{Check for updates}

\begin{abstract}
Hypertension is the most common lifestyle disorder today. Systemic arterial hypertension is that the most important modifiable risk factor for all-cause morbidity and mortality. Worldwide one of the major causes of premature death is hypertension and can lead to major health consequences, such as CHD, CHF, peripheral arterial disease, stroke, renal failure, and death. Hypertension may be a chronic and sometimes asymptomatic medical condition during which systemic blood pressure is elevated beyond normal. Fewer than half of those with hypertension are conscious of their condition and lots of others are

Modern treatment modalities are effective for the management of hypertension but pose human beings to their unwanted complications on their long-term use. The conventional antihypertensive drugs have many adverse effects $\&$ are not well tolerated which led to non-compliance, switching $\&$ discontinuation of treatment. There is no direct description of HTN in Ayurveda but based on its clinical presentation and similarity between pathogenesis factors for hypertension can be correlated with Raktagata Vata and it is considered as Tridoshaja Vyadhi. Treatment for hypertension in Ayurveda on the idea of Balancing all three Doshas. So Nidan Parivarajan, proper dietary habits, Yoga, Meditation along Ayurvedic herbs can be beneficial for balancing the state of mind, maintaining as well as
\end{abstract}


reducing blood pressure. The Ayurvedic drug's potency depends upon rasa, Guna, Virya, Vipaka \& Prabhava. Also, Acharyas have mentioned this as Prabhava of the drug. Ayurveda has various classical formulations and single herbs like Brahmi, Pushkarmoola, Jyotishamati, Sarpagandha, Saunf, Jatamansi etc. having Hridya, Kaphahara, Vatahara, Balya, Raktaprasadana, etc. properties which are safe and cost-effective too.

Keywords: High Blood Pressure, Lifestyle disorders, Raktachapa, Silent killer.

\section{INTRODUCTION}

Hypertension is one of the foremost common lifestyle disorders soon. Every person has been affected by it. Even kids are often victims of Hypertension. In about 90\% of patients, there's no known cause for hypertension and this is often vital to be alert. Hypertension itself may be a very dangerous condition. As we all know, hypertension is named a silent killer because it rarely exhibits symptoms before it damages the gut, brain, liver or kidney. The damaging of those vital organs is that the most vital explanation for death. Hypertension is a crucial worldwide public health challenge. About $26.4 \%$ of the planet adult population in 2000 had hypertension and $29.2 \%$ were projected to possess this condition by 2025 . Recent studies from India have shown the prevalence of Hypertension to be $25 \%$ in urban and $10 \%$ in rural people in India. Hypertension is usually expressed because of the ratio of the systolic BP (that is, the pressure that the blood exerts on the arterial walls when the heart contracts) and therefore the diastolic BP (the pressure when the heart relaxes). As such, the heart is forced to figure harder to beat the increased systemic pressure to deliver blood to tissues, which puts strain on the heart and arteries. Though plenty of potent antihypertensive drugs are available today none of them is free from untoward effects. Beta-blockers often cause fatigue, cold extremities, bradycardia and heart failure. Similarly, angiotensin-converting enzyme inhibitors may cause cough, rash etc, But Ayurvedic therapy can minimize the danger think about a far better way. As per Ayurvedic principles, just in case of an unknown disease, the physician should attempt to understand the character of the disease through Dosha, the location of manifestation, etiological factors then should initiate the treatment. Hence it becomes necessary to review multiple factors viz. Dosha Vradhi, Dhatu Dushti, Stratos are involved and their role in the causation of hypertension for a correct understanding of the disease, its prevention and treatment.

\section{Classification of Hypertension -}

\begin{tabular}{|l|l|l|}
\hline Category & Systolic $(\mathrm{mm} \mathrm{of} \mathrm{Hg})$ & Diastolic $(\mathrm{mm} \mathrm{of} \mathrm{Hg})$ \\
\hline Normal & $<130$ & $<85$ \\
\hline High Normal & $130-139$ & $85-89$ \\
\hline
\end{tabular}

\section{Hypertension-}

\begin{tabular}{|l|l|l|}
\hline Stage 1 HTN (Mild) & $140-159$ & $90-99$ \\
\hline Stage 2 HTN (Moderate) & $160-179$ & $100-109$ \\
\hline Stage 3 HTN (severe) & $180-209$ & $110-119$ \\
\hline Stage 4 HTN (Very severe) & $>210$ & $>120$ \\
\hline
\end{tabular}

\section{Types of Hypertensions -}

Two types of hypertensions -

1. Primary hypertension 2. Secondary hypertension.

Primary hypertension/ Essential hypertension/idiopathic hypertension- About $90-95 \%$ of cases of hypertension are categorized as primary hypertension with no obvious underlying cause. This is often found in most individuals who have crossed the centre age. It cannot be permanently cured but is controlled with the proper drugs and measures. The measures include 
sharp reduction of obesity and reduction of dietary salt.

The possible causes of primary hypertension are also such as-

1. Hereditary factor

2. Environmental factor- overcrowding, pollution.

3. Age and sex factor

4. Habit of Alcohol and smoking

5. Increase in lipid profile and serum cholesterol

6. Obesity

7. Psycho-social factors- anxiety, tension.

8. Dietary factor- more salt intake.

Secondary hypertension/ Malignant hypertension when hypertension is caused by another condition or disease process, it's called secondary hypertension. Incidence of the Secondary hypertension is relatively very low. This is often very dangerous and needs to remedy urgently. Fewer than $10 \%$ of patients have high blood pressure.

The possible causes of secondary hypertension could also be such as-

1. Due to the administration of certain drugs like contraceptive pills, steroids etc. 2. Hypertensive diseases of pregnancy: - Toxaemia of pregnancy 3. Renal causes: - Acute nephritic syndrome, chronic nephritis and polycystic kidney. 4. Endocrinal causes: - Thyrotoxicosis, myxoedema and acromegaly. 5. Metabolic causes: - Diabetes, chronic gout and atherosclerosis. 6 . Congenital diseases: - Coarctation of aorta 7. Collagenases and miscellaneous diseases: -SLE and polyarteritis nodosa. 8. Neurological: - Encephalitis, brain tumour and cerebrovascular accidents 9. Blood diseases: -Polycythaemia etc.

Symptoms of Hypertension- Most of the patients with hypertension have no specific symptoms except elevated blood pressure. Symptoms of hypertension are usually variable from time to time. The popular symptoms of hypertension are as follows.

- Headache

- Nausea

- Numbness \& burning sensation in hands \& feet

- Vertigo

- Vomiting

- Feeling of tiredness, restlessness
- Breathlessness

- Loss of appetite

- Chest pain

- Discomfort

- Bleeding from nose

- Swelling in legs and eyes

- Irritability

- Haziness of vision

Complications of Hypertension- Uncontrolled high blood pressure can lead to the following complications developed within the human body: - 1. Heart attack or stroke- High force per unit area can cause hardening and thickening of arteries (atherosclerosis), which may cause a heart attack, stroke or other cardiovascular complications. 2. Aneurysm- High blood pressure is of explanation for weakening and bulging the blood vessels, forming an aneurysm. 3. Heart failure- Heart muscle thickens thanks to the pumping of blood against the higher pressure in blood vessels. The thickened muscle may have a tough time pumping enough blood to body needs, which may cause coronary failure. 4. Organ malfunction- Weakened and narrowed blood vessels in kidneys and other organs, which prevent such organs from normal functioning. 5. Vision loss- Hypertension damages the very small blood vessels within the retina of the eyes may result in vision loss. 6. Memory problems- Uncontrolled high blood pressure is also affecting the ability of the person to think, remember and learn.

\section{Ayurveda Approach to Hypertension -}

According to Ayurveda, high vital sign involves all three Doshas, the heart, and the blood vessels. In high blood pressure, we can see signs and symptoms of disturbance of Vata Dosha that mainly of 'Vyana Vayu. Pitta dosha vitiation is additionally seen often. People with Pitta and Vata predominant constitution are more vulnerable to hypertension than the others. According to Maharshi Charaka, it's not essential to offer a selected name to each disease. In those conditions, the physicians should treat the patient to be considering the character of the disease, its sites, aetiology and Dosha-Dushya Sammurchhana. Inference of previous research work done is that hypertension is nothing but a 'Vata Pradhan Tridoshaja Vyadhi', be greatly 
influenced by Mana. Therefore, it's going to be considered as Sharir and Manas Roga (Ubhayashrita Vyadhi).

Factors involved in hypertension - Dosha Prana Vayu: Hridaya Dhruka means Dharana of the heart the function of Prana Vayu can be correlated with the vagal inhibition of systema, nervosum. Additionally, the present vaso- motor centre controls the force per unit area by the autonomic nervous system; similarly, Prana Vayu also controls the regulation of blood pressure by controlling Vyana Vayu.

Vyana Vayu: Vyan Vayu is alleged to be answerable for various kinds of movements within the body. With the help of Vyan Vayu, the heart contracts and propels blood (Rasa Rakta Dhatu) continuously everywhere in the body.

Samana Vayu: In step with Sharangadhara after the digestion process 'Samana Vayu' helps within the transportation of Rasa into the heart and from there it circulates within the whole body.

Apana Vayu: Vitiation of Apana Vayu hampers the excretion of the Purisha and Mutra affecting homeostasis which can affect vital signs. So Apana Vayu also plays a task in the regulation of blood pressure.

Avalambaka Kapha: Normal rhythm, contractility, and tone of cardiac muscles are often correlated with functions of Avalambaka Kapha. Thus, it keeps the heart in an exceedingly healthy state and enhances its continuous pumping capacity.

Agni: Agni is a crucial think about factor in the pathogenesis of all the diseases. Agni Dushti occurs at two levels Jatharagni Mandya and Dhatwagni Mandya. Jatharagni Mandya will cause Ama formation which ends in Strotorodha and vitiation of all Doshas. It'll ultimately increase peripheral resistance and may result in hypertension. Atherosclerotic changes in vessels may be an outcome of chronic Agnimandya and Ama.

Mana (Mind) There's a detailed interrelation between the body and mind (Mana). Manasik Bhavas like Krodha (anger), Chinta (worry), Bhaya (fear) etc. plays a vital role within the pathogenesis, progression and prognosis of all disease. This fact is focusing that the Mana plays important role in hypertension. Modern medical science also considers that the involvement of psycho (Mana) can be a causative factor for hypertension. In step with Ayurveda, Vayu is the regulator and stimulator of Mana. These basics of Ayurveda mustn't neglect while treating hypertension.

\section{Pathogenesis of Hypertension in Ayurveda -}

Ati Lavana Sevana (Excessive salt intake), Madyapana (Alcohol consumption) Snigdha Bhojana (oily diet) Divaswap (daytime sleep) and Manovighata (Mental incidence) result in vitiation of Shonita (blood). But Shonita being Dhatu (tissue) is not capable of vitiating Doshas (pre-mortal factors of the body) independently. The Doshas present within the Shonita is involved indirectly within the manifestation of high blood pressure. The overuse of salt, alcohol vitiates the Sadhaka pitta and Shonita (blood). Sedentary habits vitiate the Avalambaka Kapha, and psychological stress induces vitiation of Prana Vayu. Initially Prana vayu gets Prakopa. Since Prana Vayu has an influence on Hridaya (heart), vitiates Hridaya and its residing components like Vyana Vayu, Sadhaka pitta, Avalambaka Kapha. Shona is additionally involved because it is found in Hridaya. Prakupita (vitiated) Avalambaka Kapha induces exaggerated contractility of the heart, while aggravated Vyana Vayu leads to increased Gati (speed), the force of ejection of blood from Hridaya. These events result in forceful expulsion of blood through Dhamanis (blood vessels), leading to increased resistance in vessels ensuring High blood pressure.

Samprapti Ghatakas (Components of pathogenesis) Doshas: Prana, Udan \& Vyana vayu, Sadhaka Pitta, Avalambaka Kapha

Manas Dosha: Raja, Tama

Dushyas: Rasa, Rakta, Mamsa, Meda

Updhatu: Sira, Dhamani

Agni: Jatharagni-Dhatwagnimandya

Srotas: Rasavaha Raktavaha, Pranvaha \& Manovha

Srotodushti Prakar: Sanga type of srotorodha

Udabhava Sthana: Hridaya, Dhamani

Adhisthana: Mano-daihika, Sira, Dhamani, Srotas

Sancharasthana: Sarva Sharir

Rogamarga: Madhyama Rogamarga 


\section{TREATMENT/MANAGEMENT OF HTN -}

Ayurveda has three principles of management for any disease namely: 1. Nidana Parivarjana 2. Shodhana 3. Shamana

\section{Nidan parivarjan}

It means avoiding the causative and risk factors. In the case of essential hypertension, the patient should follow the following Pathya and Apathya.

1) PATHYA
VIHAR-
- Regular blood pressure check-up • Lifestyle modifications like timely intake of a
balanced diet, regular physical exercise, daily brisk walking for half an hour
- Weight reduction
- Timely sleeping and awakening.
- Regular practice of Yoga, Meditation etc. under the supervision of a Yoga expert
AAHAR-
- More use of fruits and green vegetables
- Reduce intake of oily, salty, sour and spicy food items
- More use of Barley (Yava), Sorghum (Jowar), wheat, green gram (Mudga/Moong
dal), horse gram, moringa (Shigru), Bitter gourd (karela), Bottle gourd (Ghial
Lauki), Turnip (Shalgam), Carrot (Gajar), Radish (Muli), Indian gooseberry (Amla),
Cucumber (Khira), Black grapes (Draksha), Pomegranate (Anar), Apple, Pineapple,
Cold milk etc.

\section{2) $A P A T H Y A$}

VIHAR-

- Practice of day sleeping and awakening at night.

\section{AAHAR-}

- Excessive intake of salt (sprinkling over salad, curd etc.)

- Excessive use of Butter, Ghee, Chillies (Red, Green), Pickles, Til taila, Bengal gram, Mustard oil, Sour fruits, Curd, Tea, Coffee etc.

- Intake of animal fat, processed/oily food items.

- Alcohol consumption and smoking
Shodhana Shodhana means purification of the body by eliminating morbid doshas and Dushyas from the body through panchakarma hance breaking the Samprapti of disease. Through various research done on essential hypertension, the following Shodhana therapies can be done: 1. Virechan 2. Basti-Ksheer basti, Lekhan basti, etc. 3. Nasya 4. Shirodhara- Takradhara, Jaladhara, Tailadhara, etc. 5. RaktamokshanSiravedh etc.

Shaman The principle of Shaman therapy is to normalize and maintain the equilibrium of all the Doshas. The following drugs (single/compound formulation) are commonly used for prevention and control of Hypertension

Single drugs: - Amalaki, Jyotishmati, Chhangal Jadi, Rudraksha, Haridra, Japapushpam, Jatamamsi, Punarnava, Bhringraj, Sadabahar, Sarpagandha, Shankhapushpi, Shigru, Tagar, Vacha
Compound drugs: - Arjun Ksheerpaka, Brahma Rasayan, Chandralekha Rasam, Chyavana Prasha, Guduchi Rasayanam, Jatamamsi Kwath, Jatamamsyadi Yog, Madhuparnyadi Yogam, Mahavat Vidhwansak Rasa, Mangalyakusuma Mansyadi Yog, Medhya Rasayanam, Medhya Vati, Nirvishi Sindoora Kalpa, Prasadi Vati, Prasadini Vati, Rasagandhati Vati, Rasa Sindoora, Sarpagandha Ghan Vati, Shodashang Kashaya, Vacha-Mansyadi Yog

\section{Based on the form of medicine: -}

1. Kashayam (Decoction) - Jatamansi Hima, Dashmool Kwath, Arjun Kwath, Punarnava Kwath, Mahamanjistha Kwatha 2. Choorna (Powder) Sarpaghandha Choorn, Arjuna or Gokshura, Ashawaghandha Choorna, Tagar 3. Bhasma (Rasa preparation) - Mukta Pisti, Jaharmohra Pisti, Mukta Shukti. 4. Vati (Tablet) - Sarpagandha Ghana Vati, Brahmi Vati 
Here is the list of plants that have antihypertensive properties

\begin{tabular}{|l|l|l|l|}
\hline $\begin{array}{l}\text { Drug Bo- } \\
\text { tanical }\end{array}$ & $\begin{array}{l}\text { Botanical name and } \\
\text { family }\end{array}$ & Part Used & Chemical Constituent \\
\hline $\begin{array}{l}\text { Sarpagan- } \\
\text { dha }\end{array}$ & $\begin{array}{l}\text { Rauvolfia Serpentine; } \\
\text { Apocynaceae }\end{array}$ & Root & $\begin{array}{l}\text { Ajmaline, Rescinnamine, Serpentinine, Sarpagine, Deserpidine, } \\
\text { And Chandrine }\end{array}$ \\
\hline Arjun & $\begin{array}{l}\text { Termenalia Arjuna; } \\
\text { Combretaceae }\end{array}$ & Bark & $\begin{array}{l}\text { Tannins, Triterpenoid Saponins, Flavonoids, Gallic Acid, Ellagic } \\
\text { Acid, Calcium, Magnesium, Zinc, }\end{array}$ \\
\hline $\begin{array}{l}\text { Ashwagan- } \\
\text { dha }\end{array}$ & $\begin{array}{l}\text { Withania Somnifera; } \\
\text { Solanaceae }\end{array}$ & Whole Plant & $\begin{array}{l}\text { Alkaloids Include Withanine, Withananine, Pseudowithanine, } \\
\text { Somnine, Somniferine, Somniferinine. }\end{array}$ \\
\hline Bhringraj & $\begin{array}{l}\text { Eclipta prostrata } \\
\text { IEclipta alba; Aster- } \\
\text { aceae }\end{array}$ & Leaves & $\begin{array}{l}\text { Wedelolactone And Dimethyl Wedelolactone, Ascorbic Acid. Al- } \\
\text { kaloid, Ellipticine. Thiophene Derivatives Mono-, Di- And Terthi- } \\
\text { ophene Acetylenes }\end{array}$ \\
\hline Punarnava & $\begin{array}{l}\text { Boerhavia diffusa; } \\
\text { Nyctaginaceae }\end{array}$ & Whole Plant & $\begin{array}{l}\text { Punarnava Contains B-Sitosterol, A-2- Sitosterol, Palmitic Acid, } \\
\text { Ester of B- sitosterol, Tetracosanoic, Hexacosanoic, }\end{array}$ \\
\hline Shatavari & $\begin{array}{l}\text { Asperagus Recemosus; } \\
\text { Asparagaceae }\end{array}$ & $\begin{array}{l}\text { Tuberous } \\
\text { Dried Root }\end{array}$ & $\begin{array}{l}\text { Saponins-Shatavarins I-IV. Shatavarin IV Is a Glycoside of } \\
\text { Sarsasapogenin. Dried Root Yields Sitosterol; (Dihydroxy Hy- } \\
\text { droxy isobutyl }\end{array}$ \\
\hline
\end{tabular}

Mode of Action of Shaman Drugs- 1. Centrally acting- Withania (CNS acting), rauwolfia (catecholamine depilators), hypericum (dopamine and norepinephrine reuptake inhibitors), black cumin seed (CNS acting and antioxidant) 2. Vasodilators- Garlic (Via Hyperpolarization through $\mathrm{H} 2 \mathrm{~S}$ ), Ginseng (Direct Smooth Muscle Relaxant), Hawthorn, Vitis, Yarrow, Olive Leaf (Endothelium Dependent Vasodilation), Forskolin (Adenyl Cyclase Pathway), Lotus 3. Diuretic - Punarnava, Kalaaja 4. ACE inhibitors- Garlic (by allicin), Vacha, Bibhitaki, Pippali 5. Calcium channel antagonist- Shunthi, Brahmi 6. Cholesterol Synthesis Inhibitors- Cat's claw, African mistletoe 7. Hypolipidemic- Matulunga, Amlavetas, Vrikshamla, Pushkarmool

Diet- Dietary modification is extremely important to stop the event of hypertension or potentially combat and reduce high blood pressure. Lowering sodium intake (especially from table salt) reduces excessive water retention, which helps maintain normal blood pressure. Excessive use of common salt is toxic and damaging to arteries and other tissues, which can initiate atherosclerosis and lead to hypertension. Additional dietary changes beneficial for reducing blood pressure include adopting a diet that is rich in fruits, vegetables, whole grains and low-fat dairy products, reducing consumption of sugar and heavily processed food, reducing caffeine intake, and limiting alcohol consumption.

Yoga - Stress reduction from practising meditation, yoga, and other mind-body relaxation techniques can lower blood pressure. Yoga is formulated for several reasons and therefore the health restoration is one among them. Shavasana, Sukhasana, Dhanurasana, Makarasana, Vajrasan, along with the regular practice of Pranayama are found to be very useful for lowering blood pressure in normal as well as hypertensive individuals if performed accurately. According to Bruhadaranyaka and Chhandogya Upanishads, the aim of Pranayama and Yogic techniques is to control Prana. This target is difficult to achieve, but mental peace and relaxation thus achieved could be used as a therapeutic tool. This factor could also be important in the primary prevention of coronary atherosclerosis.

\section{CONCLUSION}

Essential hypertension is a deadly disease leading to many cardiovascular, cerebral and renal diseases. It has been found that the share of hypertensive patients is rising sharply. Antihypertensive drugs can help to control blood pressure, but they will not cure permanently high blood pressure. Humans today is looking towards Ayurveda in a search of a perfect and safe 
treatment. Hence to urge the right management of hypertension with no side effects may be needed in the present era. In the Ayurveda equilibrium of Doshas, Dhatus, Malas and Agni are considered as a healthy state of an individual. In nutshell, we will say that while observing hypertension through Ayurvedic spectacle one or more of the subsequent three possibilities should be considered. 1. Pathophysiological changes in the form of vitiation of Dosha (Vata, Pitta and Kapha), Dhatu and Mala Dushti. 2. Psychological changes i.e., disturbances at the extent of Mana (Manovaha Strotas Vikara). 3. Structural changes as complications of long-term hypertension on various organs like heart, blood vessels, kidney etc. After a thorough study of literature and fundamentals in both Ayurveda and Modern medicine, it's concluded that the Ayurvedic approach to treat a disease consistent with its Samprapti (pathogenesis). Hypertension can also manage by well following Pathya and Apathya Aahar-Vihar (diet management and appropriate lifestyle) and Yoga mentioned in Ayurveda. An additional benefit of Ayurvedic management is the absence of hazardous effects which is very important in view of the global acceptance of Ayurveda.

\section{REFERENCES}

1. Siddharth N. Shah. API Textbook of Medicine, 7 th edition, 2003; 457-459.

2. Siddharth N. Shah. API Textbook of Medicine, 7 th edition, 2003, 430-432.

3. Charak Samhita, Yadavji Trikamji, Reprint edition, Chaukhamba Sanskrit sansthana, Varanasi,2009, Sutrasthan 18/46;108

4. Taber's cyclopaedic Medical Dictionary, 20th edition, 2005; 268.

5. WHO report of Prevention and control for cardiovascular diseases, 2001-2002, available from http://www.sld.cu/./pdf/./international cardiovascular disease statistics?

6. Welton P.K, Global burden of hypertension: an analysis of worldwide data, The Lancet, 365 (9455), 2005, 217- 223

7. S.D. Pier Domenico et al. "Prognostic value of different indices of blood pressure arability in hypertensive patients." American Journal of Hypertension. 2009

8. Suzanne Oparil S, Zaman MA, Calhoun DA (November 2003). "Pathogenesis of hypertension Ann. Intern. Med. 139 (9): 761-76. Doi:10.7326/0003-4819-139-9200311040- 00011.PMID 14597461.
9. "Hypertension: e Medicine Nephrology". Retrieved 2009-06-05.

10. Devin K. Binder et al 'Idiopathic Intracranial Hypertension, Neurosurgery; Volume 54, Number 3, March 2004; 538-552.

11. Vriddha Vagbhata, Ashtanga Samgraha (Shashilekha commentary of Indu), edited by Shiva Prasad Sharma, 2nd ed, Chaukhamba Sanskrit series office, Varanasi, 2008, Sutrasthana 20/6: 156

12. Vaidya Yadunandan Upadhayaya editor. Ashtanghridyam: Sutra sthana 13/25, Varanasi: Chaukhamba Prakashana; 8th ed.pg. 111.

13. Sharangadhara, Sharangadhara Samhita, edited by Shailaja Shrivastava, Reprint edition, Chaukhamba Orientalia, Varanasi, 2009, Poorvakhanda 6/8, 52.

14. Charaka Samhita, Vaidya Yadavaji Trikamaji Acharya, Chaukhmba Surbharati prakashana, reprint 2000, Ch. Su.12.

15. Dhananjay Patel et.al, Role of Manas Bhavas in the etiopathogenesis of Uccharaktachapa (EHT) and its management with Medhya Rasayana and Shirodhara MD thesis, GAU, Jamnagar, 2003.

16. Chaukhamba prakashana; 8th:1119. Unknown author, hypertension. ccras. Available from: http://www.ccras.nic.in/sites/default/files/viewpdf/faq/hypertension.pdf

17. Atul kale. A clinical study on the ayurvedic samprapti of essential hypertension and its management with sarpagandhadi vati. Thesis-kayachikitsa, jamnagar;2005:14-16

18. Manish Agrawal, d. Nandini, Vikas Sharma and n. S. Chauhan; - herbal remedies for the treatment of hypertension; international journal of pharmaceutical sciences and research (2010), vol. 1, issue 5:1-21

19. R.J. Padwal et al. "The 2010 Canadian Hypertension Education Program recommendations for the management of hypertension: Part 2 - Therapy." The Canadian Journal of Cardiology. 2010,26(5):249-258.

20. M.V. Renforth et al. "Stress Reduction Programs in Patients with Elevated Blood Pressure: A Systematic Review and Meta-analysis." Current Hypertension. 2007, 9(6):520-8.

\section{Source of Support: Nil Conflict of Interest: None Declared}

How to cite this URL: Garima Yadav et al: Management Of Hypertension - An Ayurvedic Review. International Ayurvedic Medical Journal \{online\} 2021 \{cited October 2021\} Available from:

http://www.iamj.in/posts/images/upload/2465_2471.pdf 